\title{
Pengaruh Asupan Susu terhadap Tinggi Badan dan Berat Badan Anak Sekolah Dasar
}

\author{
${ }^{1}$ Valentino J. Matali \\ ${ }^{2}$ Herlina I. S. Wungouw \\ ${ }^{2}$ Ivonny Sapulete
}

\author{
${ }^{1}$ Program Studi Pendidikan Dokter Fakultas Kedokteran Universitas Sam Ratulangi Manado \\ ${ }^{2}$ Departemen Fisiologi Fakultas Kedokteran Universitas Sam Ratulangi \\ Email: valentinomatali@gmail.com
}

\begin{abstract}
Milk, a sustenance containing nutrition such as carbohydrate, protein, fat, and mineral, is beneficial in the growth and development of a child. The level of milk consumption in Indonesia is still categorized as low. According to Statistic Center Agency, consumption of milk in Indonesia only reached as much as $12.1 \mathrm{~L} /$ capita each year, much lower from Finland that reached $361 \mathrm{~L} /$ capita. Nationwide prevalence of short stature (according to Height/Age) among children aged 5-12 year old is $30.7 \%$ (12.3\% very short and $18.4 \%$ short). Prevalence of thin stature among children aged 5-12 year old is $11.2 \%$ (4.0\% very thin and $7.2 \%$ thin). This study was aimed to determine the effect of milk intake towards the growth of height and weight of elementary school children. This was an experimental study performed on 40 subjects divided into 20 experimental subjects of SD GMIM 34 Manado and 20 control subjects of SD GMIM Betlehem Manado. All experimental subjects were given $250 \mathrm{ml}$ UHT low fat high calcium milk intake for 60 days while control subjects were not given any milk intake. Data were analyzed with the independent $\mathrm{T}$ test for the effect of milk towards height and the Mann Whitney $U$ test for the effect of milk towards weight. The independent $\mathrm{T}$ test showed a $P$ value of 0.000 meanwhile the Mann Whitney U test showed a $P$ value of 0.989 . Conclusion: Milk intake influenced height growth but did not significantly influence weight gain in elementary school children.
\end{abstract}

Keywords: milk, height growth, weight gain

\begin{abstract}
Abstrak: Susu merupakan bahan pangan yang mengandung zat gizi seperti karbohidrat, protein, lemak dan mineral yang bermanfaat dalam pertumbuhan dan perkembangan seorang anak. Tingkat konsumsi susu di Indonesia masih tergolong rendah. Menurut Badan Pusat Statistik (BPS), konsumsi susu di Indonesia hanya 12,1 L/ kapita per tahun, jauh lebih rendah dari Finlandia yang mencapai $361 \mathrm{~L} / k a p i t a$. Secara nasional prevalensi pendek (menurut $\mathrm{TB} / \mathrm{U}$ ) pada anak usia 5-12 tahun ialah $30,7 \%$ (12,3\% sangat pendek dan $18,4 \%$ pendek). Prevalensi kurus pada anak usia 5-12 tahun ialah $11,2 \%$, terdiri dari $4,0 \%$ sangat kurus dan $7,2 \%$ kurus. Penelitian ini bertujuan untuk mengetahui pengaruh asupan susu terhadap pertumbuhan tinggi badan dan berat badan anak sekolah dasar. Penelitian ini merupakan penelitian eksperimental pada 40 subyek yang terbagi menjadi 20 orang subjek perlakuan yang berasal dari SD GMIM 34 Manado dan 20 orang subjek kontrol dari SD GMIM Betlehem Manado. Subjek perlakuan diberikan asupan $250 \mathrm{ml}$ susu UHT low fat high calcium setiap hari selama 60 hari sedangkan subjek kontrol tidak diberikan asupan. Penelitian ini menggunakan uji $\mathrm{T}$ independen untuk pengaruh susu terhadap tinggi badan dan uji Mann Whitney U untuk pengaruh susu terhadap berat badan. Pada uji T indepenen didapatkan $P=0,000$ sedangkan pada uji Mann Whitney U didapatkan $P=0,989$. Simpulan: Asupan susu berpengaruh terhadap pertumbuhan tinggi badan namun tidak berpengaruh secara bermakna terhadap berat badan anak sekolah dasar.
\end{abstract}

Kata kunci: susu, pertumbuhan tinggi badan, pertumbuhan berat badan 
Pertumbuhan seorang anak dipengaruhi oleh faktor internal dan eksternal. Salah satu faktor eksternal yang penting pada anak untuk diketahui adalah gizi. Gizi harus diperhatikan dengan sangat baik karena tumbuh dan kembang seorang anak bergantung pada asupan gizi yang diperoleh. ${ }^{1}$ Makanan yang dibutuhkan anak usia sekolah harus memiliki sumber energi yang berasal dari karbohidrat, protein, dan lemak. Zat gizi mikro seperti mineral dan vitamin juga diperlukan tubuh. Zat-zat gizi tersebut dapat membantu proses partumbuhan badan anak. ${ }^{2}$

Susu merupakan salah satu bahan pangan yang diketahui kaya akan zat gizi yang sangat penting dalam memenuhi kebutuhan gizi seorang anak. Susu merupakan salah satu jenis makanan dan minuman yang memiliki kandungan gizi yang cukup lengkap yang diperlukan oleh semua kelompok usia. ${ }^{3}$

Meskipun susu memiliki manfaat yang baik bagi kesehatan manusia namun tingkat konsumsi susu di Indonesia masih sangat rendah. Menurut Badan Pusat Statistik (BPS), masyarakat Indonesia mengonsumsi susu hanya 12,1 L/kapita/tahun, sangat berbeda dengan negara lain seperti Finlandia yang mencapai 361 L/kapita/ tahun, Swedia $355 \mathrm{~L} / \mathrm{kapita} / \mathrm{tahun}$, dan Belanda 320 L/kapita/tahun. Tingkat konsumsi susu di Indonesia bahkan lebih rendah disbanding negara-negara tetangga seperti Malaysia 50,9 L/kapita/tahun, Singapura 44,5 L/kapita/tahun dan Thailand 33,7 L/kapita/tahun. ${ }^{5,6}$

Anak yang mengonsumsi susu memiliki status gizi yang lebih baik. Indikator status gizi yang digunakan untuk kelompok usia 5-12 tahun didasarkan pada hasil pengukuran antropometri berat badan (BB) dan tinggi badan (TB) yang disajikan dalam bentuk tinggi badan menurut umur (TB/U) dan Indeks Massa Tubuh menurut umur (IMT/U) . Secara nasional prevalensi pendek (menurut $\mathrm{TB} / \mathrm{U}$ ) pada anak usia 512 tahun ialah $30,7 \% \quad(12,3 \%$ sangat pendek dan $18,4 \%$ pendek). Prevalensi kurus (menurut IMT/U) pada anak usia 512 tahun ialah $11,2 \%$, terdiri dari $4,0 \%$ sangat kurus dan 7,2\% kurus. Masalah gemuk pada anak usia 5-12 tahun masih tinggi yaitu $18,8 \%$, terdiri dari gemuk $10,8 \%$ dan sangat gemuk (obesitas) $8,8 \%$. Prevalensi pendek dan sangat pendek (stunting) pada usia 5-12 tahun di Sulawesi Utara ialah 30,8\%. Prevalensi kurus anak usia sekolah di Sulawesi Utara pada anak laki-laki 9\% dan anak perempuan 7,4\% sedangkan prevalensi berat badan lebih pada laki-laki 9,2\% dan anak perempuan $8 \%$. $^{7,8}$

Tujuan penelitian ini ialah untuk mengkaji pengaruh asupan susu terhadap tinggi badan dan berat badan anak sekolah dasar.

\section{METODE PENELITIAN}

Jenis penelitian ini ialah eksperimental. Penelitian dilaksanakan pada bulan Septem-ber-Desember 2017 dan bertempat di SD GMIM 34 Manado dan SD GMIM Betlehem Manado. Pemilihan sampel penelitian menggunakan cara purposive sampling dengan jumlah sampel sebanyak 40 orang yang terbagi menjadi 20 orang kelompok perlakuan dari SD GMIM 34 Manado dan 20 orang kelompok kontrol dari SD GMIM Betlehem Manado. Dalam penelitian ini kelompok perlakuan diberikan $250 \mathrm{ml}$ susu low fat high calcium setiap hari selama 60 hari sedangkan kelompok perlakuan tidak diberikan asupan susu.

Penelitian ini menggunakan data primer yaitu dengan melakukan pengukuran tinggi badan dan berat badan sebelum perlakuan dan sesudah perlakuan serta menggunakan kuesioner untuk melihat kebiasaan minum susu responden. Data yang didapat diolah dengan menggunakan Microsoft Excell dan Statistical Package and Social Science 23 (SPSS).

\section{HASIL PENELITIAN}

Berdasarkan jenis kelamin, subyek penelitian pada kelompok perlakuan terdiri dari 11 (55\%) laki-laki dan 9 (45\%) perempuan, sedangkan yang berada dalam kelompok kontrol terdiri dari 9 (45\%) lakilaki dan $11(55 \%)$ perempuan (Tabel 1). 
Tabel 1. Karakteristik subyek penelitian berdasarkan jenis kelamin

\begin{tabular}{ccccc}
\hline & \multicolumn{2}{c}{ Laki-laki } & \multicolumn{2}{c}{ Perempuan } \\
& Jumlah & $\%$ & Jumlah & $\%$ \\
\hline Perlakuan & 11 & 55 & 9 & 45 \\
Kontrol & 9 & 45 & 11 & 55 \\
Jumlah & 20 & 100 & 20 & 100 \\
\hline
\end{tabular}

Berdasarkan usia, subyek penelitian pada kelompok perlakuan paling banyak berusia 9 tahun dengan jumlah 11 orang (55\%). Subyek penelitian dengan usia 11 tahun merupakan usia tertua pada kelompok perlakuan yang mengikuti penelitian ini dengan jumlah 2 orang (10\%). Subyek penelitian pada kelompok kontrol paling banyak berusia 9 tahun dengan jumlah 9 orang $(45 \%)$. Subyek penelitian dengan usia 11 tahun merupakan usia tertua pada kelompok kontrol yang mengikuti penelitian ini dengan jumlah 3 orang (15\%) (Tabel 2).

Tabel 2. Karakteristik subyek penelitian berdasarkan usia

\begin{tabular}{ccccccccc}
\hline \multirow{2}{*}{ Kelompok } & \multicolumn{7}{c}{ Usia (tahun) } \\
\cline { 2 - 9 } & 8 & $\%$ & 9 & $\%$ & 10 & $\%$ & 11 & $\%$ \\
\hline Perlakuan & 1 & 5 & 11 & 55 & 6 & 30 & 2 & 10 \\
Kontrol & 0 & 0 & 9 & 45 & 8 & 40 & 3 & 15 \\
\hline
\end{tabular}

Rerata tinggi badan kelompok perlakuan pada pengukuran pertama ialah 133,23 $\mathrm{cm}$ dan pengukuran kedua $134,785 \mathrm{~cm}$, sedangkan rerata tinggi badan kelompok kontrol pada pengukuran pertama adalah $131,525 \mathrm{~cm}$ dan pengukuran kedua 132,52. Rerata kenaikan tinggi badan kelompok perlakuan ialah $1,555 \mathrm{~cm}$ sedangkan rerata kenaikan tinggi badan kelompok kontrol $0,995 \mathrm{~cm}$ (Gambar 1).

Rerata berat badan kelompok perlakuan pada pengukuran pertama ialah $28,775 \mathrm{~kg}$ dan pengukuran kedua $30,66 \mathrm{~kg}$, sedangkan rerata berat badan kelompok kontrol pada pengukuran pertama ialah $29,48 \mathrm{~kg}$ dan pengukuran kedua $31,42 \mathrm{~kg}$. Rerata kenaikan tinggi badan kelompok perlakuan ialah $1,885 \mathrm{~kg}$ sedangkan rerata kenaikan tinggi badan kelompok kontrol
$1,94 \mathrm{~cm}$ (Gambar 2).

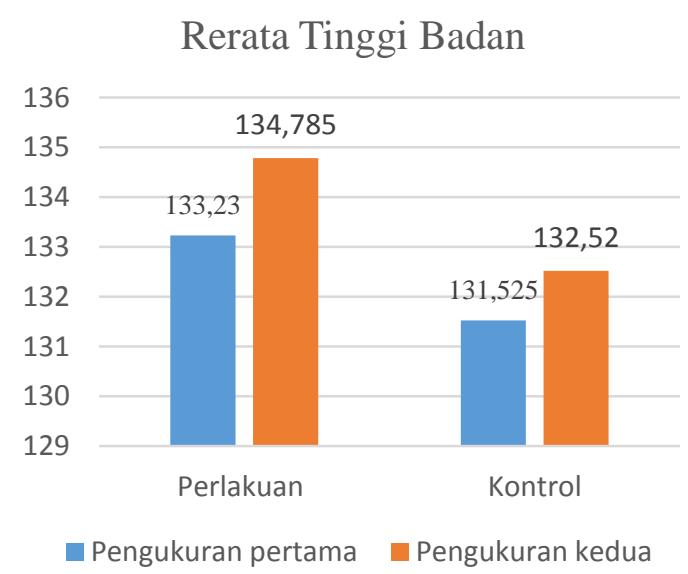

Gambar 1. Karakteristik subyek penelitian berdasarkan rerata tinggi badan

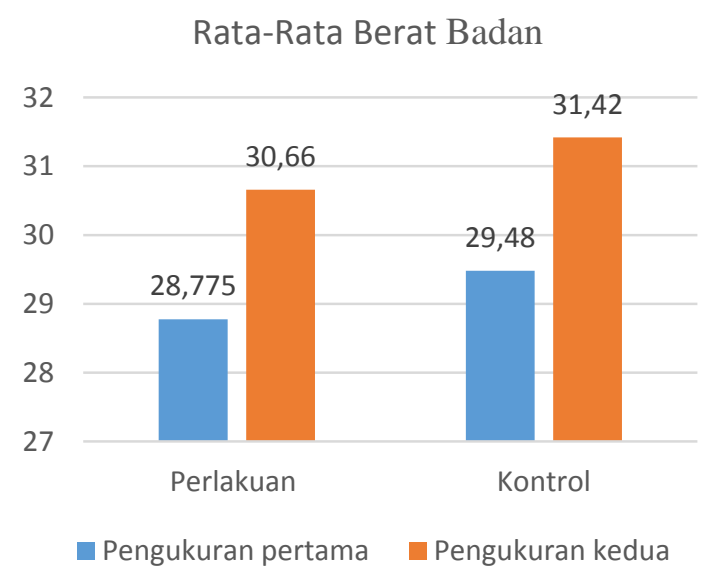

Gambar 2. Karakteristik subyek penelitian berdasarkan rata-rata berat badan

Pada seluruh subyek penelitian baik kelompok perlakuan maupun kelompok kontrol tidak ada yang mengonsumsi susu setiap hari. Pada kelompok perlakuan terdapat 11 subyek yang mengonsumsi susu sebanyak 1-2 kali dalam seminggu, 1 subyek yang mengonsumsi susu sebanyak 3-4 kali dalam seminggu dan 8 subyek yang tidak mengonsumsi susu. Pada kelompok kontrol terdapat 8 subyek yang mengonsumsi susu sebanyak 1-2 kali dalam seminggu, 2 subyek yang mengonsumsi susu sebanyak 3-4 kali dalam seminggu dan 10 subyek yang tidak mengonsumsi susu (Tabel 3). 
Tabel 3. Karakteristik subyek penelitian berdasarkan kebiasaan minum susu

\begin{tabular}{cccccc}
\hline & \multicolumn{5}{c}{ Kebiasaan Minum Susu } \\
\hline & $\begin{array}{c}\text { Setiap minggu } \\
(\mathrm{x} / \text { minggu })\end{array}$ & Tidak & $\begin{array}{c}\text { Jumlah } \\
\text { (n) }\end{array}$ \\
& $1-2$ & $3-4$ & $>5$ & & \\
\hline Perlakuan & 11 & 1 & 0 & 8 & 20 \\
Kontrol & 8 & 2 & 0 & 10 & 20 \\
\hline
\end{tabular}

Hasil uji t indepen mendapatkan nilai Sig. (2-tailed) $<0,05$ yang berarti terdapat perbedaan bermakna rerata kenaikan tinggi badan pada kelompok perlakuan dan kelompok kontrol sehingga dapat dikatakan bahwa asupan susu berpengaruh terhadap pertumbuhan tinggi badan.

Hasil uji Mann Whitney U mendapatkan nilai $P>0,05$ yang berarti tidak terdapat perbedaan bermakna selisih pengukuran berat badan pertama dan kedua antara kelompok perlakuan dan kelompok kontrol sehingga dapat dikatakan bahwa asupan susu tidak berpengaruh terhadap peningkatan berat badan.

\section{BAHASAN}

Berdasarkan hasil analisis SPSS diketahui bahwa terdapat perbedaan tinggi badan kelompok perlakuan dan kelompok kontrol pada pengukuran sebelum dan sesudah pemberian asupan susu pada kelompok perlakuan sehingga asupan susu berpengaruh terhadap tinggi badan anak sekolah dasar. Hasil penelitian ini sejalan dengan penelitian oleh Orr $^{9}$ tahun 1928 yang merupakan penelitian pertama yang menun-jukkan adanya pengaruh asupan susu terhadap tinggi badan. Dalam penelitian ini, anak sekolah di Inggris dibagi menjadi tiga kelompok yang diberikan asupan susu skim, biskuit, dan yang tidak diberikan asupan. Perubahan tinggi badan terjadi pada anak usia 5-6 tahun, 8-9 tahun dan 13 tahun. Anak yang diberikan asupan susu skim memiliki kenaikan tinggi badan yang lebih baik daripada anak yang hanya diberikan biskuit dan yang tidak diberikan asupan.

Penelitian yang hampir sama dilakukan oleh Du et al. ${ }^{10}$ tahun 2004 pada 698 anak perempuan berusia 10-12 tahun di China dengan tingkat konsumsi susu dan kalsium yang rendah. Dalam penelitian ini, responden yang diberikan asupan susu tinggi kalsium sebanyak $330 \mathrm{ml}$ selama periode 2 tahun dan lima kali dalam seminggu menunjukkan peningkatan tinggi badan yang lebih baik daripada responden yang tidak diberikan asupan susu. Penelitian yang dilakukan oleh Lampl et al. ${ }^{11}$ pada anak usia 7-13 tahun di New Guinea yang diberikan 20 gram susu skim bubuk dalam jangka waktu 8 bulan menunjukkan peningkatan tinggi badan hampir dua kali lipat daripada yang tidak diberikan susu skim bubuk.

Penelitian potoang lintang yang dilakukan oleh Black et al. ${ }^{12}$ tahun 2002 terhadap 250 anak di New Zealand menunjukkan 50 anak yang menghindari minum susu secara bermakna lebih pendek $(2,78-4,13 \mathrm{~cm})$ daripada 200 anak yang mengonsumsi susu. ${ }^{12}$ Penelitian yang dilakukan oleh Grillenberg ${ }^{13}$ pada 554 anak sekolah dengan rata-rata usia 7,1 tahun di Kenya menunjukkan hasil sebaliknya. Dalam penelitian ini, responden yang diberi asupan susu selama 2 tahun tidak bertumbuh secara signifikan lebih baik daripada yang diberikan asupan daging dan yang tidak diberikan asupan. Hanya anak dengan kategori pendek yang mengalami pening-katan tinggi badan secara signifikan lebih baik daripada subjek control.

Hasil penelitian ini sesuai dengan teori yang mengatakan bahwa terdapat pengaruh asupan susu terhadap tinggi badan. Susu mengandung zat gizi yang diperlukan untuk pertumbuhan seorang anak. Kalsium, Vitamin D, Fosfor dan Protein merupakan zat gizi yang terdapat dalam susu yang sangat penting dalam pembentukan tulang dan pertumbuhan seorang anak. Kalsium dan fosfor berperan dalam penguatan dan pertumbuhan tulang yang penyerapannya dibantu oleh vitamin D. Selain itu di dalam susu juga terkandung Insuline Like Growth Factor-1 (IGF-1) yang merupakan faktor pertumbuhan panjang tulang. IGF-1 distimulasi oleh growth hormone dan berperan dalam meningkatkan aktivitas 
osteoblast dan proliferasi serta diferensiasi sel tulang sehingga terjadi pembentukan dan pertumbuhan tulang.

Berdasarkan hasil analisis SPSS juga diketahui bahwa tidak terdapat perbedaan bermakna berat badan kelompok perlakuan dan kelompok kontrol pada pengukuran sebelum dan sesudah pemberian asupan susu pada kelompok perlakuan sehingga tidak terdapat pengaruh signifikan asupan susu terhadap berat badan anak sekolah dasar. Hasil penelitian ini serupa dengan penelitian yang dilakukan Kim et al. ${ }^{14}$ terhadap 664 remaja di Korea yang menunjukkan bahwa konsumsi susu dan produk olahannya meningkatkan densitas tulang dengan tidak meningkatkan berat badan.

Pertumbuhan berat badan sangat dipengaruhi oleh jumlah asupan zat gizi yang dikonsumsi setiap hari oleh seseorang serta aktifitas fisik yang dilakukan. Apabila jumlah kalori yang masuk tidak sesuai dengan jumlah kalori yang keluar maka akan mempengaruhi penumpukan massa jaringan seseorang. Susu kaya akan protein yang berfungsi dalam pertumbuhan jaringan, namun apabila asupan zat gizi lain tidak adekuat maka pertumbuhan berat badan akan tidak maksimal. Usia sekolah merupakan masa dimana anak akan memiliki aktifitas yang meningkat sehingga dibutuhkan energi dan asupan gizi yang adekuat.

Kekurangan dalam penelitian ini adalah peneliti tidak meneliti lebih lanjut mengenai jumlah asupan makanan yang diterima responden dan aktifitas fisik yang sangat berpengaruh terhadap berat badan sese-orang. Peneliti juga tidak mengetahui tinggi badan orang tua, berat badan orang tua, panjang badan lahir serta berat badan lahir responden yang menunjukkan faktor genetik yang juga berpengaruh terhadap partum-buhan dan perkembangan seorang anak.

\section{SIMPULAN}

Dari hasil penelitian terhadap anak sekolah dasar dapat disimpulkan bahwa terdapat pengaruh bermakna antara asupan susu terhadap tinggi badan anak. Tidak terdapat pengaruh bermakna antara asupan susu terhadap berat badan anak.

\section{SARAN}

Bagi orang tua disarankan untuk memberikan asupan susu terhadap anaknya karena di dalam susu terkandung nutrisi yang berpengaruh dalam pertumbuhan anak.

Perlu penelitian lanjut mengenai pengaruh asupan susu terhadap pertumbuhan dengan memperhitungkan asupan makanan setiap hari yang dikonsumsi anak serta menyertakan faktor genetik, dan dengan jangka waktu yang lebih lama.

\section{UCAPAN TERIMA KASIH}

Ditujukan kepada seluruh subyek penelitian dan orang tuanya atas partisipasinya, SD GMIM 34 Manado, SD GMIM Betlehem Manado, serta semua pihak yang ikut terlibat dalam penyelesaian penelitian ini.

\section{DAFTAR PUSTAKA}

1. Hidayat AAA. Buku Saku Praktikum Kebutuhan Dasar Manusia. Jakarta: EGC, 2004

2. Judarwanto, Widodo. Perilaku makan anak sekolah. 2012. [cited 2017 Aug 10]. Available from: http://gizi.depkes.go.id/ wpcontent/uploads/2012/05/perilakumakan-anak-sekolah.pdf

3. Untoro, Rachmi. Depkes: Susu Salah Satu Sumber Gizi Terlengkap, 2008.

4. FAO. Milk and Milk Product. [cited 2017 Aug 12]. Available from: www.fao.org

5. Chartsbin. Current Worldwide Total Milk Consumption per Capita. 2007. [cited 2017 Aug 19]. Available from: www.chartsbin.com.

6. Tingkat Konsumsi Susu Orang Indonesia. Jakarta: Badan Pusat Statistik, 2015.

7. Hartoyo, Sulaeman A, Syarief, Yulianti LN. Dampak konsumsi susu dan pengasuhan terhadap pertumbuhan dan perkembangan anak 2-5 tahun di Kota Bogor. Media Gizi dan Keluarga. 2007; 31:27-30.

8. Riset Kesehatan Dasar (Riskesdas). Badan Penelitian dan Pengembangan Kesehatan Kementerian RI. 2013. 
[cited 2017 Aug 20]. Available from: http://www.depkes.go.id/resources/dow nload/general/Hasil\%20Riskesdas\%20 2013.pdf.

9. Orr JB. Milk consumption and the growth of school-children. Lancet. 1928;1:202-203.

10. Du X, Xhu K, Trube A, Zhang Q, Ma G, Hu X, et al. School-milk intervention trial enhance growth and bone mineral accretion in Chinese girls at aged 10-12 years in Beijing. Br J Nutr. 2004;92(1): 159-68.

11. Lampl M, Johnston FE, Malcolm LA. The effects of protein supplementation on the growth and skeletal maturation of New Guinean school children. Ann Hum Biol. 1978;5:219-227.
12. Black RE, Williams SM, Jones IE, Goulding A. Children who avoid drinking cow milk have low diet- ary calcium intakes and poor bone health. Am J Clin Nutr. 2002;76:675-680.

13. Grillenberger M, Neumann CG, Murphy SP, Bwibo NO, van't Veer P, Hautvast JGAJ, West CE. Food supplements have a positive impact on weight gain and the addition of animal source foods increases lean body mass of Kenyan schoolchildren. J Nutr. 2003; 133:3957S-3964S.

14. Kim SH, Kim WK, Kang MH. Effect of milk and milk products consumption on physial growth and bone mineral density in Korean adolescent. Nutr Res Pract, 2013;7(4):309-14. 
Jurnal e-Biomedik (eBm), Volume 5, Nomor 2, Juli-Desember 2017 